\title{
Hydrologic characteristics immediately after seasonal burning on introduced and native grasslands
}

\author{
WILLIAM E. EMMERICH AND JERRY R. COX
}

\begin{abstract}
Authors are soil scientist, USDA-ARS, Southwest Watershed Research Center, 2000 East Allen Road, Tucson, Ariz. 85719; and range scientist, USDA-ARS, Forage and Range Res. Lab., Utah State Univ., Logan 84322.
\end{abstract}

\begin{abstract}
Fire on rangelands used as a management tool or as an unwanted wildfire removes vegetation cover. Vegetation cover is thought to be a dominate factor controlling surface runoff and erosion. Vegetation removal by a burn should have an immediate effect on runoff and erosion. Surface runoff and sediment production were evaluated immediately after fall and spring season burns at 2 locations with different soil and vegetation types for 2 years in southeastern Arizona. The evaluations were conducted with a rainfall simulator at 2 precipitation intensities. Immediately after a burn there was not a significant change in runoff and erosion, therefore, vegetation cover by itself was concluded not to be a dominate factor controlling surface runoff and erosion. The increase found in surface runoff and sediment production from the burn plots was not significantly greater than the natural variability for the locations or seasons. Significantly higher surface runofi and sediment production was measured in the fall season compared to the spring at 1 location.
\end{abstract}

Key Words: surface runoff, erosion, rainfall simulator, vegetation cover, control burn, spatial variability

Prescribed burning is frequently used as a vegetation management tool on rangelands. The objectives are to: increase herbage yields, utilization and availability, improve wildlife habitat, control undesirable shrubs, prepare a mineral seedbed for grass establishment, and control various diseases (e.g., liver fluke and brownspot) (Wright 1974, Stoddart et al. 1975). The season of the burn influences the results and effectiveness of the burn treatment (Pase 1971, Pase and Knipe 1977, Whisenant et al. 1984, Cox 1988, Whisenant and Uresk 1990). These and other studies have been concerned primarily with changes in vegetation composition and not with potential changes in surface runoff and erosion.

Burning removes plant cover and leaves the surface soil unprotected to raindrop impact and may also produce hydrophobic substances that can reduce infiltration (DeBano et al. 1970, DeBano et al. 1976, Richardson and Hole 1978). Increases in runoff and erosion after burning have been reported (Wright et al. 1976, 1982). Most evaluations of the burn effect are commonly conducted with a double-ring infiltrometer or small sprinkler using a single intensity (Wood 1987, Knight et al. 1983, Roundy et al. 1978, Ueckert et al. 1978). These methods may be inadequate for 2 reasons. First, natural precipitation has variable intensity and distinct results may be obtained at different intensities, and second, significant spatial variability in infiltration (Merzougi and Gifford

Authors wish to thank Dr. Gary Richardson for assistance in statistical analyses and Howard Larsen, Jim Smith, Art Dolphin, and John Smith for field work. The authors acknowledge Bill Kruse and USDA-FS for providing water and land at the Santa Rita Experimental Range, and John Donaldson and USDI-BLM for providing water and land at the Empire-Cienega Resource Conservation Arca.

Manuscript accepted 26 Dec. 1991.
1987, Devaurs and Gifford 1984). The results of a small simulator may be influenced by the spatial variability in infiltration. A large rainfall simulator would average spatial variability and allow for a more precise determination of a burn treatment effect.

Seasonal burning effects have been reported, with decreased infiltration from a late spring burn (McMurphy and Anderson 1965). Simanton and Renard (1982) showed seasonal differences in infiltration and runoff without burning. Further evaluation is needed on the interaction of seasonal burning and infiltration, surface runoff, and erosion.

Understanding changes in surface runoff and erosion caused by rangeland burns or seasonal influences is important for making range management decisions or modeling hydrologic responses. The premise has been that surface vegetation cover is a dominant factor controlling surface runoff and erosion. If vegetation cover by itself is a dominate factor controlling surface runoff and erosion, changes should be immediately evident after vegetation removal by a burn. The objective of this study was to evaluate the effect of vegetation removal by seasonal burning on surface runoff and erosion immediately after a burn on 2 vegetation and soil types.

\section{Materials and Methods}

\section{Study Areas}

The Santa Rita Experimental Range and Empire-Cienega Resource Conservation Area in southeastern Arizona were selected as study sites because of their different vegetation and soil types. Soil at the Santa Rita location is a White House gravelly loam (Fine, mixed, thermic Ustollic Haplargids) with 5 to $6 \%$ slope. The surface $10 \mathrm{~cm}$ of soil contained $1.0 \%$ organic matter, $17 \%$ rock fragments $(>2 \mathrm{~mm})$, and 68,22 , and $10 \%$ sand, silt, and clay, respectively, in the $<2 \mathrm{~mm}$ fine earth fraction. Almost a pure stand of Lehmann lovegrass (Eragrostis lehmanniana Nees), an introduced species which is spreading over large areas of the Southwest (Cox and Ruyle 1986, Cox et al. 1989), covered the Santa Rita site and had not been grazed for a year prior to the study. Aboveground standing biomass on individual plots ranged from 2,200$5,900 \mathrm{~kg} / \mathrm{ha}$ and litter from $600-2,900 \mathrm{~kg} / \mathrm{ha}$. Mean annual precipitation for the location is $423 \mathrm{~mm}$ with $60-70 \%$ as summer thunderstorms.

The soil at the Empire location is a Hathaway gravelly sandy loam (Loamy-skeletal, mixed, thermic Aridic Calciustolls) with 5 to $7 \%$ slope. The surface $10 \mathrm{~cm}$ contained $1.7 \%$ organic matter, $14 \%$ rock fragments, and 66,22 , and $12 \%$, sand, silt, and clay, respectively, in the $<2 \mathrm{~mm}$ fine earth fraction. The Empire site is dominated by native black grama [Bouteloua eriopoda (Torrey) Torrey], hairy grama (Bouteloua hirsuta Lagasca), and sideoats grama [Bouteloua curtipendula (Michaux) Torrey]. Individual plot aboveground standing biomass ranged from $700-4,200 \mathrm{~kg} / \mathrm{ha}$ and litter from $120-900 \mathrm{~kg} / \mathrm{ha}$. The pasture had not been grazed for 
1.5 years before the study. Mean annual precipitation at the location is $400 \mathrm{~mm}$ with $60-70 \%$ as summer thunderstorms.

\section{Experimental Design and Data Analysis}

Thirty-two 25 by $25-\mathrm{m}$ plots, with two 3.05 by $10.66-\mathrm{m}$ rainfall simulator subplots, were established at each location and fenced to exclude grazing. The treatments at each site were a burn and nonburn (control). Four blocks containing each treatment were established at the locations. Fall and spring seasons were evaluated with adjacent control and burn plots randomly selected within each block. The treatments were repeated for 2 years and at each location there were 4 control and burn plots used for each season and year.

The experimental design was a split plot with location as main plots. Subplots consisted of randomized complete block design with season by year factors in 4 blocks. The sub-subplot factor was treatment effect of burn vs control. Two subsample data values were obtained from each sub-subplot, providing a measure of subsampling error. Analysis of variance techniques were used to analyze the data. The subsample variance was found to be significantly less than the split error term. Therefore, the appropriate split plot error terms were used to test all effects. Main effects were either pooled or separated depending on the significance of the interactions $(P \leq 0.05)$. Main effect means were separated with a least significant difference test (LSD).

\section{Experimental Procedure}

In the fall (October 1987-88) and spring (April 1988-89) for 2 years four 25 by $25-\mathrm{m}$ plots at each location were burned starting with a back and finishing with a head fire. The prescribed burns were of low intensity and short duration that consumed the aboveground standing biomass to within $3-10 \mathrm{~cm}$ of the plant crowns and $90 \%$ of the litter.

Rainfall simulations were conducted at each location in the fall and spring seasons on 4 control and burn plots with a modified Swanson rotating boom simulator to allow 2 rainfall rates by controlling the number of open nozzles (Swanson 1965, Simanton et al. 1985). Rainfall was applied to the 2 rainfall simulator subplots at a rate of $55 \mathrm{~mm} / \mathrm{hr}$ for $45 \mathrm{~min}$ and for $110 \mathrm{~mm} / \mathrm{hr}$ for 15 min. Simulator energies were about $80 \%$ of natural rainfall (Simanton et al. 1985). The rainfall simulator intensities of 55 $\mathrm{mm} / \mathrm{hr}$ for $45 \mathrm{~min}$ and $110 \mathrm{~mm} / \mathrm{hr}$ for $15 \mathrm{~min}$ have been observed in the previous 13 years of Santa Rita location rainfall intensity data (unpublished data). Metal borders were inserted into the soil on top and sides to prevent inflow or outflow of surface runoff on the simulator subplots. At the bottom of the subplots a metal head wall and trough collected and directed surface runoff through a calibrated flume. Surface runoff rates were continuously recorded throughout each rainfall simulation event. The time runoff started after the start of rainfall was recorded. Runoff rates were integrated over the simulation event to calculate runoff volumes for the first $45 \mathrm{~min}$, last $15 \mathrm{~min}$, and total for the event. One liter runoff water and sediment samples were collected from the flumes at periodic intervals during each simulation event. Sampling intervals were dependent on changes in the runoff rate and ranged from 1 to 5 minutes with more frequent sampling during rapidly changing discharge rate. Runoff-sediment samples were weighted, allowed to settle, decanted, dried at $60^{\circ} \mathrm{C}$, reweighed, and sediment concentrations calculated. The product of the discharge rate and sediment concentration was integrated to estimate sediment production for the first $\mathbf{4 5} \mathrm{min}$, last $\mathbf{1 5} \mathrm{min}$, and the total from each subplot.

\section{Results and Discussion}

There was no significant treatment effect or interaction between location, season, or year for surface runoff and sediment produc- tion for the first $\mathbf{4 5} \mathrm{min}$, last $15 \mathrm{~min}$, the total event, or time of runoff as indicated by the analysis of variance even at a probability level of $P \leq 0.15$. Combining locations, seasons, and years and comparing control and burn means gave further evidence that immediately after treatment there was no detectable burn effect (Table 1). There was, however, a nonsignificant trend for increased

Table 1. Control and burn means for surface runoff, sediment production, and time to runoff from rainfall simulator events combining data from locations, seasons, and years.'

\begin{tabular}{|c|c|c|c|}
\hline Treatment & $\begin{array}{l}\text { Surface } \\
\text { runoff }\end{array}$ & $\begin{array}{l}\text { Sediment } \\
\text { production }\end{array}$ & $\begin{array}{l}\text { Time to } \\
\text { runoff }\end{array}$ \\
\hline $\begin{array}{l}\text { Control } \\
\text { Burn }\end{array}$ & $\begin{array}{c} \\
1.91(3.40) \\
2.28(4.09)\end{array}$ & $\begin{array}{c}\text { First } 45 \mathrm{~min} . \\
25(47) \\
34(67)\end{array}$ & $\begin{array}{l}15.2(16.6) \\
14.5(15.6)\end{array}$ \\
\hline $\begin{array}{l}\text { Control } \\
\text { Burn }\end{array}$ & $\begin{array}{l}3.86(4.41) \\
4.74(6.10)\end{array}$ & $\begin{array}{l}\text { Last } 15 \mathrm{~min} . \\
50(56) \\
72(87)\end{array}$ & \\
\hline $\begin{array}{l}\text { Control } \\
\text { Burn }\end{array}$ & $\begin{array}{l}5.77(7.50) \\
7.01(9.96)\end{array}$ & $\begin{array}{c}\text { Total } \\
76(98) \\
106(145)\end{array}$ & \\
\hline
\end{tabular}

${ }^{1}$ Values in parenthesis are S.D.

surface runoff and sediment production and decreased time to runoff on the burn plots.

The burn treatment removed the standing biomass and litter cover to expose surface soil to raindrop impact energy. There was no effect of the vegetation removal by the burn treatment on surface runoff or erosion immediately after the burns. This agrees with other rainfall simulation studies which showed little differences in infiltration, runoff, and sediment production conducted on rangelands just after the standing biomass was removed by clipping (Johnson and Blackburn 1989, Simanton et al. 1991). The results of this study and others lead to the conclusion that aboveground standing biomass and litter by themselves are not a dominate factor controlling surface runoff and erosion in rangeland environments.

There have been studies on small burned watersheds averaging $45 \%$ slope that have shown increases in surface runoff that stabilized in 4 to 5 years on unseeded watersheds and in 1 to 2 years on seeded watersheds (Wright et al. 1976, 1982). Sediment production stablized when surface cover reached 53 to $72 \%$ depending on the precipitation for the year. Our rainfall simulations were conducted immediately after the burns and there could be a time factor involved before the treatment effect becomes detectable. In a pinyon-juniper woodland, infiltration evaluated on dry soil after a burn was similar to that on unburned areas (Roundy et al. 1987). One year later infiltration under shrub canopies tended to be lower and sediment production tended to increase with age of the burn. Ueckert et al. (1978) found a decrease in soil aggregate sizes after a burn. These effects persisted longer than 5 years. Thurow et al. (1986) suggested that the function of aboveground biomass is to protect the surface soil from the disaggregating effect of direct raindrop impact. Raindrop energy from postburn events can destroy soil aggregates at the surface and clog soil pores or form a crust that would restrict infiltration and enhance runoff and erosion (Smith et al. 1990). Rangeland soils with erosion pavement (surface gravel) protecting the surface and vegetation removed by clipping produced small changes in runoff and erosion with time (Simanton and Renard 1985). Erosion pavement was not on the soils in this study. The process of aggregate destruction and/or crust formation probably takes a number of events to complete and our evaluation was the first event, hence, the nonsignificant treat- 
ment effect immediately after the burn.

The hypothesis that rainfall intensity could be important in determining a treatment effect was not confirmed by the results. The ratios of sediment production to runoff for the control and burn treatments were calculated from Table 1 to be 13 and 15 $\mathrm{kg} / \mathrm{ha} / \mathrm{mm}$, respectively, and were the same for both rainfall intensities. This indicated a treatment responded the same irrespective of the rainfall intensity.

Studies in Utah have shown extreme spatial variability for infiltration on rangelands to a point that measurements taken on a 2-m grid interval have no correlation (Achouri and Gifford 1984, Merzougui and Gifford 1987). In New Mexico on a herbaceous dominated rangeland, 1 to 5 small plots $\left(1-\mathrm{m}^{2}\right)$ were needed to achieve $\pm 20 \%$ of the mean infiltration rate with $90 \%$ probability, but sediment production required up to 256 plots (Wood 1987). The rainfall simulator used in this study averaged small scale spatial variability over a large plot area plus the number of subplots would reduce larger scale spatial variability to a minimum. Therefore, spatial variability should not have prevented the determination of a treatment effect if it was greater than the natural variability.

Plots of runoff rates and sediment concentration vs time in Figures 1,2,3, and 4 illustrate spatial variability and the response to rainfall intensity. The runoff rates and sediment concentrations generally followed the same patterns with time on adjacent control and burn plots and subplots containing the same treatment. The exceptions were when there was runoff only on 1 treatment of the paired plots (Fig. 1) or large differences between subplots on the same treatment (Fig. 3). These differences were a measure of the

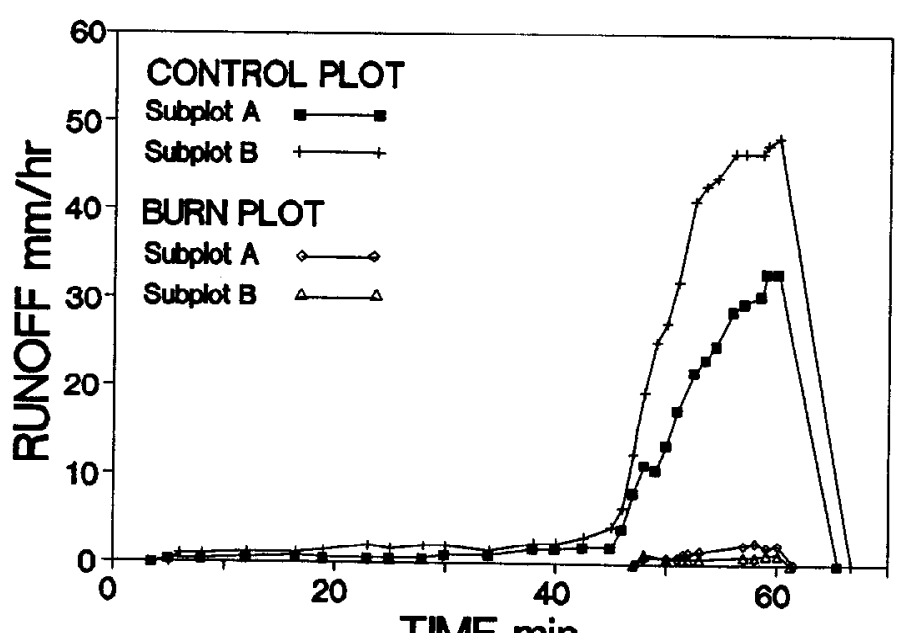

Fig. 1. Surface runoff rates vs time on a control and burn plot at the Santa Rita location.

natural variability in runoff and erosion and apparently not related to a treated effect. The response of runoff rates and sediment concentrations to rainfall intensity was further evidence of the absence of a treatment effect. The runoff rates changed with the changes in rainfall intensity and showed no preference with treatment. Sediment concentrations peaked on the treatments at the start of runoff and usually showed a second peak that was lower than the first when the precipitation intensity was increased. Sediment peaks almost always came before the runoff rate had reached equilibrium from the applied precipitation intensity (Figs. $2 \& 4$ ). Sediment concentration decreasing with time indicated there was a limited amount of soil available for transport. Even on the burn treatment, direct raindrop impact on the soil surface could not significantly increase the amount of soil dislodged and transported.

A significant season by location interaction was found for surface runoff and sediment production after combining treatments

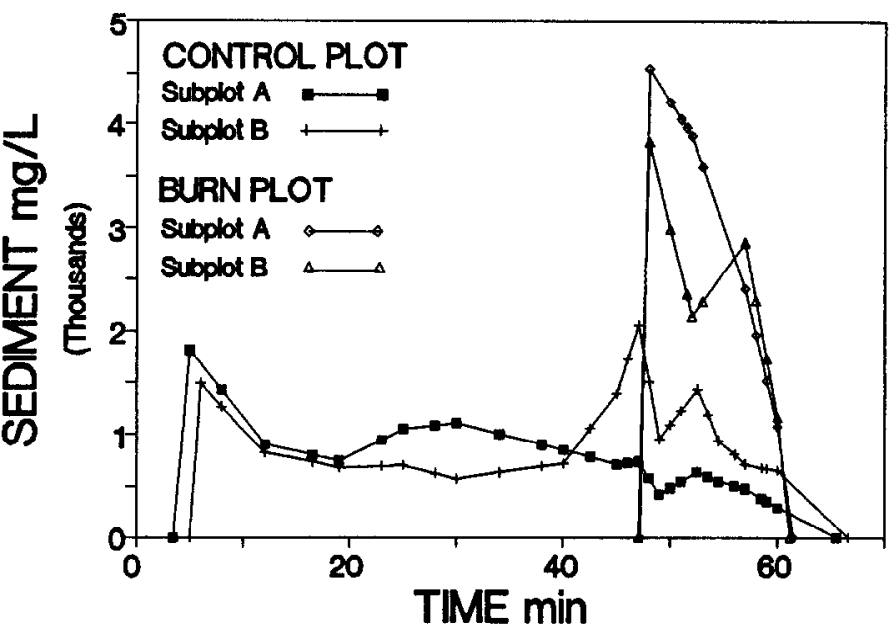

Fig. 2. Sediment concentrations vs time on a control and burn plot at the Santa Rita location.

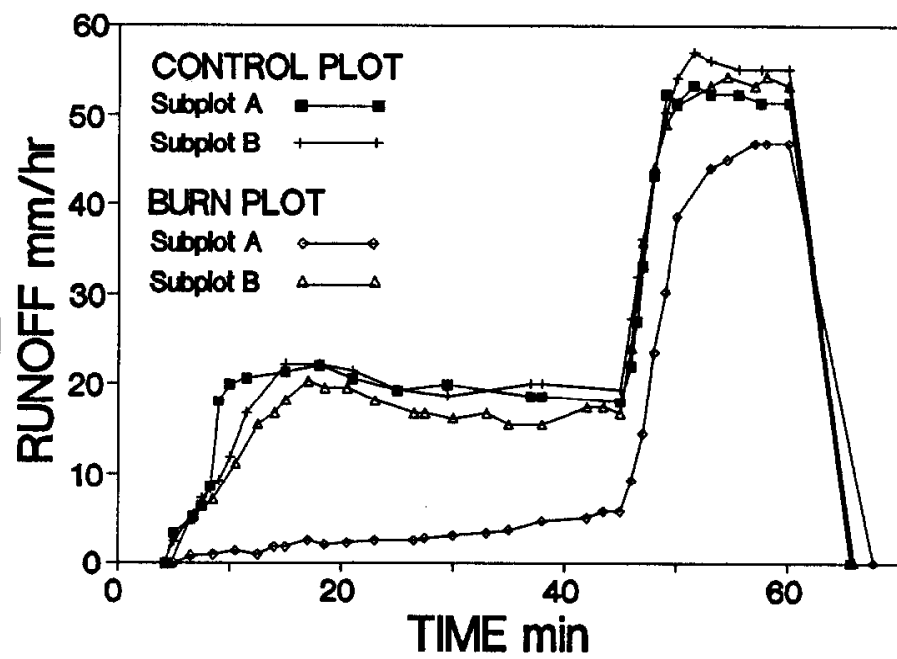

Fig. 3. Surface runoff rates vs time on a control and burn plot at the Empire location.

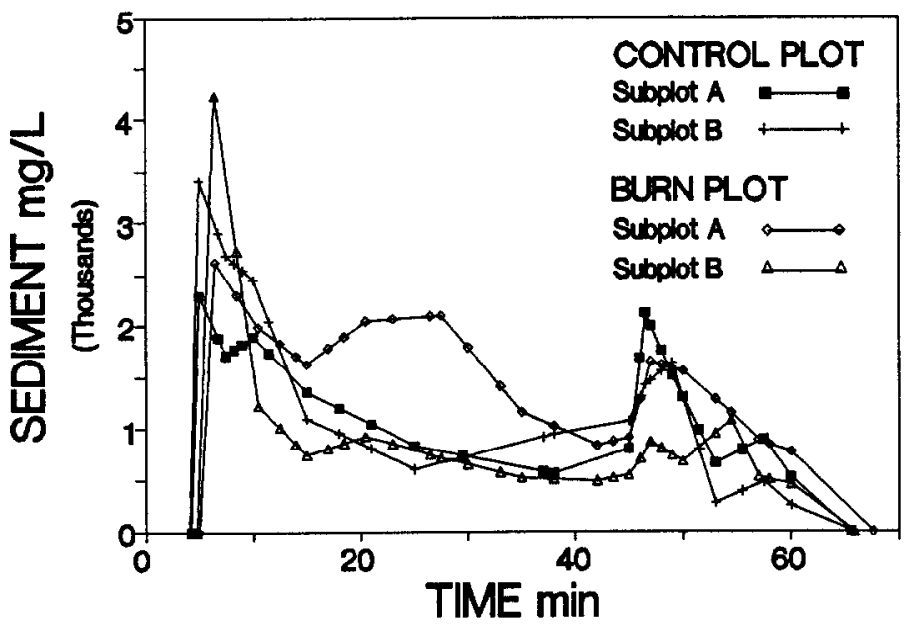

Fig. 4. Sediment concentrations vs time on a control and burn plot at the Empire location. 
Table 2. Mean surface runoff and sediment production per rainfall simulator event by location and season combining treatment data.

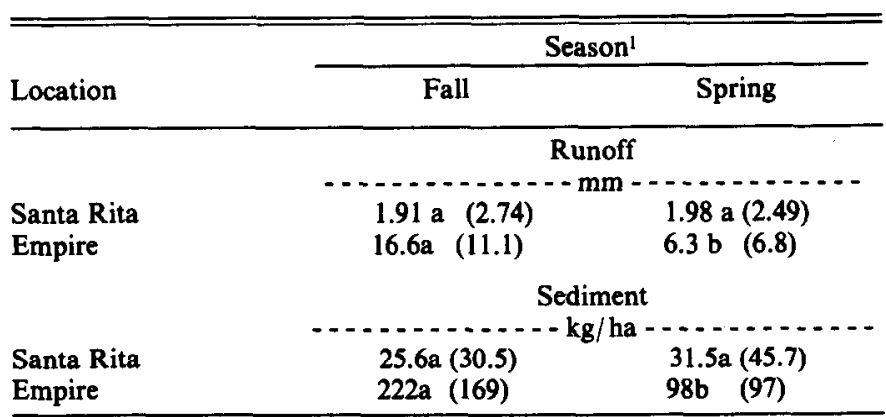

1Within rows, data followed by different letters are significantly different LSD $(P<0.05)$. Values in parenthesis are S.D.

$(P=0.05)$. Seasonal differences in runoff and sediment were not found at the Santa Rita location (Table 2). The amount of surface runoff was low and averaged about $3 \%$ of the applied precipitation. The Empire location had significantly greater runoff and sediment production in the fall. In the fall the runoff averaged $24 \%$ of the applied rainfall. These results on surface runoff support other studies that have shown the spring season to exhibit higher infiltration rates (Achouri and Gifford 1984, Schumm and Lusby 1963, Tricker 1981). The seasonal infiltration differences may be due to frost action and soil biological activity (Achouri and Gifford 1984, Simanton and Renard 1982, Gifford 1979). Detailed data on frost action or soil biological activity were not collected, but evidence of freeze-thaw activity was observed at the Empire location. The higher fall sediment production at the Empire location was attributed to the increase in runoff.

\section{Summary and Conclusions}

There was no significant burn treatment effect on surface runoff or sediment production as measured by rainfall simulator events immediately after treatment. Two different rainfall intensities on the bare soil of the burn treatment did not produce a significant increase in surface runoff or sediment production. These findings indicated that vegetation cover by itself is not the dominate factor controlling surface runoff and erosion at our study sites. Vegetation cover may interact with or influence other factors that are actually controlling surface runoff and erosion. The small increase in surface runoff and sediment production on the burn plots was within the natural variability of the 2 vegetation and soil types evaluated. A significant increase in surface runoff and sediment production in the fall compared to the spring season was found at 1 of the 2 locations.

\section{Literature Cited}

Achouri, M., and G.F. Gifford. 1984. Spatial and seasonal variability of field measured infiltration rates on a rangeland site in Utah. J. Range Manage. 37:451-455.

Cox, J.R. 1988. Seasonal burning and mowing impacts on Sporobolus wrightii grasslands. J. Range Manage. 41:12-15.

Cox, J.R., and G.B. Ruyle. 1986. Influence of climatic and edaphic factors on the distribution of Eragrostis lehmanniana Nees in Arizona, USA. J. Grassl. Soc. So. Afr. 3:25-29.

Cox, J.R., J.L. Stroehlein, and J.H. Fourie. 1989. Climate and edaphic conditions at Eragrostis lehmanniana Nees sites in Arizona, USA and the Cape Province, RSA and potential seeding sites in Southern Africa. J. Grassl. Soc. So. Afr. 6:139-145.

DeBano, L.F., L.D. Mann, and D.A. Hamilton. 1970. Translocation of hydrophobic substances in soil by burning. Soil Sci. Amer. Proc. 34:130-133.
DeBano, L.F., S.M. Savage, and D.A. Hamilton. 1976. The transfer of heat and hydrophobic substances during burning. Soil Sci. Amer. J. 40:779-782.

Devaurs, M., and G.F. Gifford. 1984. Variability of infiltration within large runoff plots on rangelands. J. Range Manage. 37:523-528.

Johnson, C.W., and W.H. Blackburn. 1989. Factors contributing to sagebrush rangeland soil loss. Trans. Amer. Soc. Agr. Engr. 32:155-160.

Knight, R.W., W.H. Blackburn, and C.J. Scifres. 1983. Infiltration rates and sediment production following herbicide/fire brush treatments. J. Range Manage. 36:153-157.

McMurphy, W.E., and K.L. Anderson. 1965. Burning Flint Hills range. J. Range Manage. 18:265-296

Merzougui, M., and G.F. Gifford. 1987. Spatial variability of infiltration rates on a semiarid seeded rangeland. Hydrol. Sci. 32:243-250.

Pase, C.P. 1971. Effect of a February burn on Lehmann Lovegrass. J. Range Manage. 24:454-456.

Pase, C.P., and O.D. Knipe. 1977. Effect of winter burning on herbage cover on a converted chaparral watershed. J. Range Manage. 30:346-348.

Richardson, J.L., and F.D. Hole. 1978. Influence of vegetation on water repellency in selected western Wisconsin soils. Soil Sci. Amer. J. 42:465-467.

Roundy, B.A., W.H. Blackburn, and R.E. Eckert, Jr. 1978. Influence of prescribed burning on infiltration and sediment production in the pinyon-juniper woodland, Nevada. J. Range Manage. 31:250-253.

Schumm, S.A., and G.C. Lusby. 1963. Seasonal variation of infiltration capacity and runoff on hillslopes in western Colorado. J. Geophys. Res. 68:3655-3666

Simanton, J.R., C.W. Johnson, J.W. Nyhan, and E.M. Romney. 1985. Rainfall simulation of rangeland erosion plots, p. 11-17. In: L.J. Lane (ed.) Proc. Rainfall Simulator Workshop 14-15 Jan. 1985, Soc. Range Manage. Denver, Colo.

Simanton, J.R., and K.G. Renard. 1982. Seasonal change in infiltration and erosion from USLE plots in southeastern Arizona. Proc. Ariz. Sec., AWRA-Hydrology Sec., Ariz. Acad. Sci. 12:37-46.

Simanton, J.R., and K.G. Renard. 1985. Time related changes in rangeland erosion, p. 18-22. In: L.J. Lane (ed.) Proc. Rainfall Simulator Workshop 14-15 Jan. 1985, Soc. Range Manage. Denver, Colo.

Simanton, J.R., M.A. Weltz, and H.D. Larsen. 1991. Rangeland experiments to parameterize the water erosion prediction project model: vegetation canopy cover effects. J. Range Manage. 44:276-282

Smith, H.J.C., G.J. Levy, and I. Shainberg. 1990. Water-droplet energy and soil amendments: effect on infiltration and erosion. Soil Sci. Soc. Amer. J. 54:1084-1087.

Swanson, H.P. 1965. Rotating-boom rainfall simulator. Trans. Amer. Soc. Agr. Engr. 8:71-72.

Stoddart, L.A., A.D. Smith, and T.W. Box. 1975. Range management Third Edition. McGraw-Hill Book Company, New York, N.Y.

Thurow, T.L., W.H. Blackburn, and C.A. Taylor, Jr. 1986. Hydrologic characteristics of vegetation types as affected by livestock grazing systems, Edwards Plateau, Texas. J. Range Manage. 39:505-509.

Tricker, A.S. 1981. Spatial and temporal patterns of infiltration. J. Hydrol. 49:261-277.

Ueckert, D.N., T.L. Whigham, and B.M. Spears. 1978. Effects of burning on infiltration, sediment, and other soil properties in a mesquitetobosagrass community. J. Range Manage. 31:420-425.

Whisenant, S.G., D.N. Ueckert, and C.J. Scifres. 1984. Effects of fire on Texas wintergrass communities. J. Range Manage. 37:387-391.

Whisenant, S.G., and D.W. Uresk. 1990. Spring burning Japanese brome in a Western wheatgrass community. J. Range Manage. 43:205-208.

Wood, M.K. 1987. Plot numbers required to determine infiltration rate and sediment production on rangelands in south central New Mexico. $J$. Range Manage. 40:259-263.

Wright, H.A. 1974. Range burning. J. Range Manage. 27:5-11.

Wright, H.A., F.M. Churchill, and W.C. Stevens. 1976. Effects of prescribed burning on sediment, water yield, and water quality from dozed juniper lands in central Texas. J. Range Manage. 29:294-298.

Wright, H.A., F.M. Churchill, and W.C. Stevens. 1982. Soil loss, runoff, and water quality of seeded and unseeded steep watersheds following prescribed burning. J. Range Manage. 35:382-385. 